\title{
DTM 及び衛星データを用いた地すべり危険地域の抽出
}

\section{Landslide Risk Mapping with use of DTM (Digital Terrain Model) and Remote Sensing Data}

\author{
高 木 方 隆* \\ Masataka TAKAGI
}

\author{
村 井 俊 治** \\ Shunji MURAI
}

\begin{abstract}
In this study, characteristics of landslide is considered from Remote Sensing data and DTM (Digital Terrain Model). A hill shading map, a sumit level map and a drinage pattern map were generated from DTM. A vegetation map and a landcover map were generated from LANDSAT TM as remote sensing data. From these maps, almost landslides were near an abundance of water resource which is stream or rice field. And landslide might be related with water erosion in topographical level.

We suggest to use slope stability analysis for prediction of landslide. Generally, slope stability analysis has been applied to only the area where landslide had been occurred. However, we attempt to apply it to all areas regardless of landslide occurrence. A method of landslide risk mapping has been developed with use of Remote sensing data, DTM and ground survey data of geology and soil mechanics. The proposed method will be useful for preparedness of landslide prevention in the wide and steep terrain such as SHIKOKU Island, JAPAN where landslides occurred very often.
\end{abstract} キーワード: リモートセンシング，DTM，地形，安定解析

\section{1.はじめに}

様々な地球観測衛星は膨大なデー夕を送り続けており， 環境・海洋・資源等の各分野で解析が進められ良い成果 を修めている。地すべりの分野においても衛星データを 利用した解析が行われているが, 地すべりは地形・地質・ 土質・水文など様々な要素が複雑に絡み合って発生する ため, 地表の状態しか反映されていない衛星データのみ から解析することは非常に困難である。

一方, DTM (Digital Terrain Model) を用いた解析 が, コンピュータの性能向上に伴って容易に行なえるよ うになった。DTM とは, 対象地域を任意の大きさの格子 で区切り, 各格子点における標高值をデータセットとし たものであり，この DTM を使用することにより，地形 解析や流出解析を簡単に行うことが出来る。

衛星データ・DTM は，ともにグリッド（格子）データ であることから両者を重ね合わせて考察すれば，今まで 以上に衛星デー夕を有効に利用できると考えられる。そ こで本研究は四国のいわゆる破砕帯地すべりを対象に, DTM 及び衛星データを用いて地すべり地の分布状況を 考察し, 地すべり危険度の判定を試みる。つまり DTM より傾斜図・切峰面図・水系図を, 衛星データより植生

* 東京大学生産技術研究所

** アジア工科大学
図・土地被覆分類図を作成し，地すべり地の分布状況を 検討する。さらにこれらデー夕を用いて斜面安定解析手 法に基づいた地すべり危険地域の抽出を試みる。

地すべり危険地域の抽出は, 航空写真による地すべり 形状の目視判読, 現地調査による統計的な解析など様々 な試みがなされているが, 前者の方法は熟練が必要であ り, 後者の方法は多大な労力が必要である。そこで, 斜 面安定解析手法に基づき, 衛星データと DTM を用いた 危険度判定図の作成法を提案する。斜面安定解析は通常 地すべりや斜面崩壊などの発生した简所を対象に, その 安定工法の考察のために行われてきた。本研究は地すべ りのあるなしに関わらず，対象地域全ての斜面について 斜面安定解析を行い, 地すべり危険度判定図を作成する ものである。

\section{DTM・街星データを用いた地すべり地域の 分布}

徳島県と高知県の県境付近を対象地域 $(13 \mathrm{~km} \times 14$ $\mathrm{km}$ )として考察を行う（図一1）。本対象地域における地 質は三波川変成帯・御荷鉾帯・秩父古生層で構成されて おり, 破砕帯地すべりが非常に多く発生している地域で ある。

本研究で用いた衛星デー夕の地上分解能は $30 \mathrm{~m} て ゙$, この画像上における地すべり発生箇所は, 僅か数画素の 


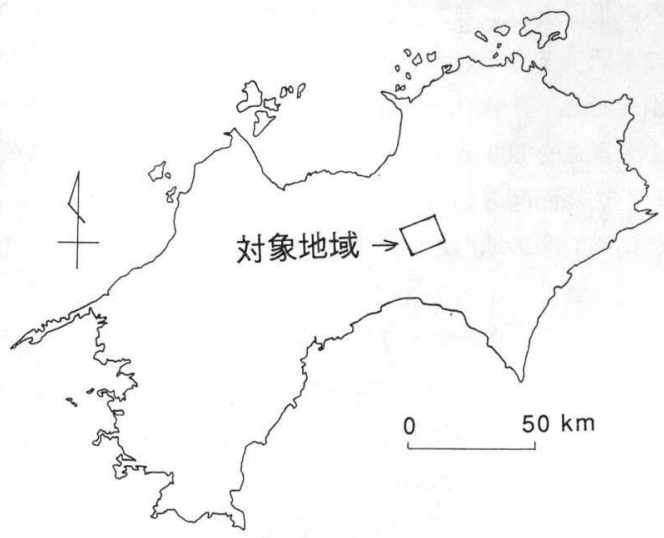

図-1 対象地域位置図

大きさでしか表現されない。そこで地すべりの分布状態 についての考察は, 行政機関である建設省及び農林省が 地すべり防止区域として指定した地域を対象に行う。地 すべり防止区域は各機関が行政的に定めた区域であるた め, その範囲はすべて地すべり発生危険地域という訳で はないが，その範囲内には地すべりが発生したブロック が必ず含まれている。したがって過去に発生した地す心゙ りの分布状況を見るには都合がよいことから, 本研究で 解析した結果を評価するために地すべり防止区域を用い た。つまり, 対象地域内の全地すべり防止区域を本章で 作成される画像上に矩形でプロットし, 地すべり発生の 分布について考察した。

\subsection{DTM を用いた地形解析}

DTM の作成はステレオ航空写真やステレオ衛星画像 を用いてイメージマッチングによって作成する方法と, 既存の地形図を用いて等高線を内挿することによって作 成する方法とがある。本研究における対象地域は地形図 が整備されていることから後者の方法でDTM を作成 した。具体的には国土地理院発行の $1 / 50,000$ 地形図 4 葉 (川口, 剣山, 大栃, 北川)を用い, 次に示す手順にした がって作成した。

a . 使用地形図 4 葉をイメージスキャナによりディジ タル化。

b.それぞれの画像を一枚の画像に合成。

c. 文字・記号認識によって等高線だけの画像を作成。

d. 等高線を内挿することによって DTM を作成。

作成されたDTM を基に本節では地形解析・流出解析 を行い地すべり地域の分布を考察する。

なお, DTM の格子幅は, 後に使用する衛星データの分 解能と同じくするため $30 \mathrm{~m}$ とした。

\section{1 .1 地すべりと地形}

図-2にDTM のシェーディング画像を示す。シェー ディング画像とは DTM を使って陰影表現を施した画

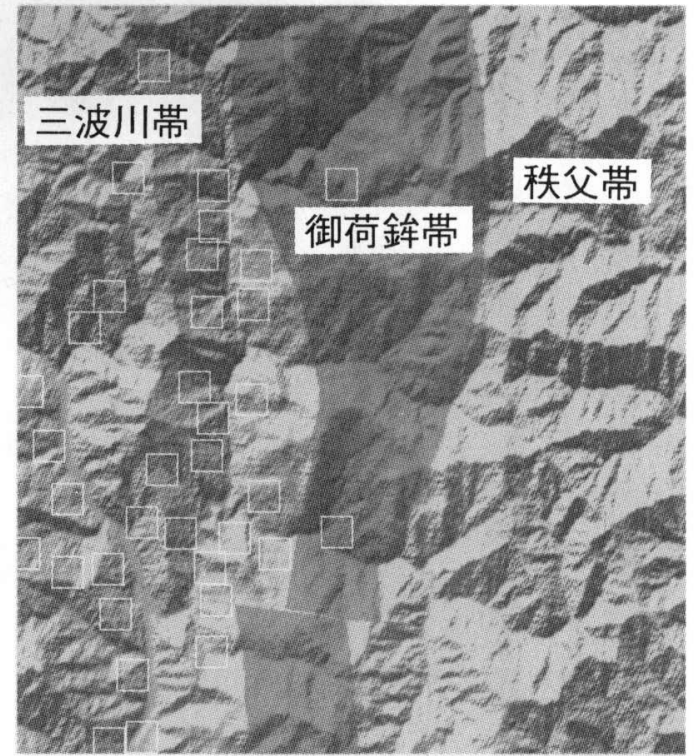

図－2 地質とシェーディング画像の合成図

像のことで, 各画素における反射光の強さは, 地表面の 法線ベクトル, 光源の方向ベクトル, 視線の方向ベクト ルからランベルトの地表反射則により計算することが出 来る6)。

$$
\begin{aligned}
I_{\lambda}=\pi F_{\lambda} \frac{A_{\lambda}}{\pi} \cos i \cdot \exp \left(-1+\frac{1}{\cos \theta}\right)^{\tau_{\lambda}} \cdots \cdots \\
s \quad: \text { 光源方向を示す単位ベクトル } \\
n \quad: \text { 斜面に垂直な単位べクトル } \\
d \quad: \text { 視線方向を示す単位ベクトル } \\
\theta \quad: \text { 光源の入射角 } \\
\cos i=n \cdot s
\end{aligned}
$$

$I_{\lambda}$ : 分光放射輝度

$A_{\lambda}$ : 分光反射率

$F_{\lambda}, \tau_{\lambda}:$ 光学的パラメータ

通常, 航空写真や衛星デー夕の画像は光源 (太陽) が 南にあるときに撮られており, 東西方向の地形形状を見 るには都合がよいが, 南北方向についてははっきりしな い場合がある。しかしシェーディング画像は光源の位置 を任意に選ぶことにより，自由に陰影を表現できるため， 傾斜だけでなくリニアメントなどの特殊な地形を認識す るのに都合がよい1)。図-2 の場合, 光源の位置を左上 30 度に設定した。さらに地形と地質とを同時に考察するた め地質図をべースに地形の陰影を表現している。

この図より, 対象地域中央部に位置する御荷鉾緑色岩 類の山岳地はなだらかな形状をしており, そのまわりに 位置する三波川带・秩父古生層の地带は急峻な地形形状 であることが判る。そして, ほとんどの地すべり地域は 三波川帯の急峻な地形（標高 $100 \sim 200 \mathrm{~m}$ ) に位置してい た。また，数は少ないものの御荷鉾帯にも地すべり地域 
が分布している。これは地質が地形形状を規制し，地す ベり発生に深く関わっていることを意味する。

\section{1 .2 地すぺりと切峰面}

切峰面とは山地の主要な峰にちょうど接するような仮 想的な面のことである。この図は地形侵食前の旧地形と 考えることが出来る。切峰面図作成法には方眼法と谷埋 め法とがあるが，計算機によって DTM から作図するに は前者の方法がアルゴリズムも簡単で適している。した がって切峰面のDTM を方眼法によって作成した。この 方法はある一定の方眼の中から最高点の標高を読みとり， その標高を方眼中心の標高として代表させることによっ て得られる。本方法で問題となる方眼の大きさは, 代表 的な山の成長曲線（山頂からの半径と起伏量との関係を あらわしたもの）を描くことによって決定した。一般に 成長曲線において, 起伏量の増加割合が小さくなるとこ

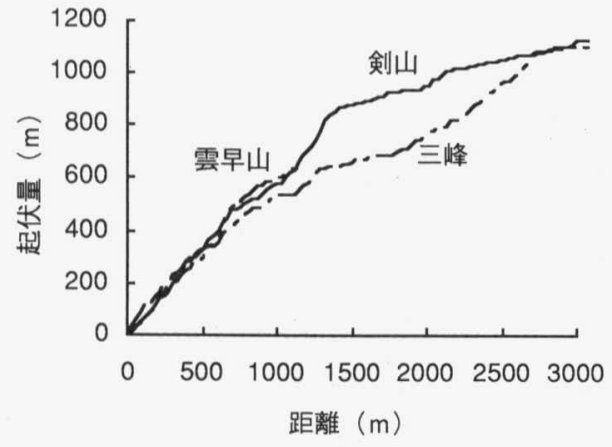

図-3 対象地域内の主な山の成長曲線

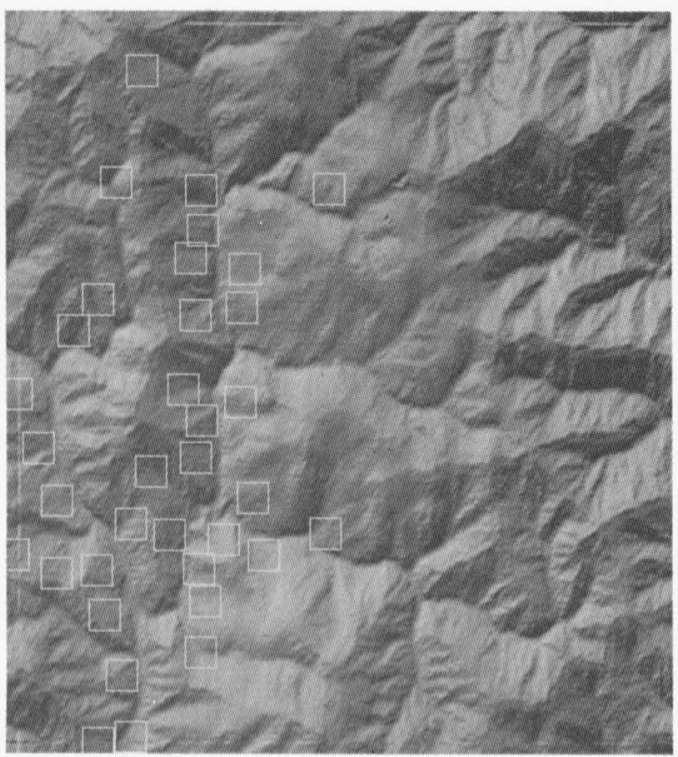

図-4 切峰面図のシェーディング画像
ろの半径を方眼の大きさとするのが良いとされているの で本研究でもそれに従った ${ }^{2)}$ 。今回は対象区域内の主な 山 (剣山, 雲早山, 三峯) の成長曲線 (図一-3) から方眼 の大きさを $600 \mathrm{~m}$ (20 画素) とした。この方眼幅で作成 した切峰面図のシェーディング画像を図ー 4 に示す。

切峰面図の地形を旧地形と見れば，現地形との標高差 をとることによって, 侵食量の分布図が作成できる (図一 5)。この図より地すべり地域は侵食量 50〜150 m の範囲 に多く分布している。つまり侵食量のあまり大きくない 地域に地すべりが発生する傾向にあると言える。

\section{1 .3 地すべりと水系}

水系は地形図上でも線記号で表されているが, 平水時 の川幅が $1.5 \mathrm{~m}$ 以上のものという既定があるため細か いものは記載されていない。そこで DTM を用いて水系 図の作成を試みた。作成には雨水の流れを上流から下流 方向へ追跡する方法で，いわゆるキネマティック法の基 礎式を基にしている3)。

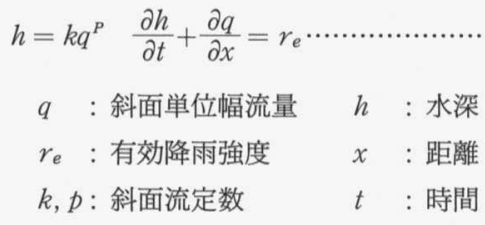

この基礎式を DTM の各画素に適用し，河川の合流点 における水深が一定 (定常状態)になるまで降水をDTM に与えて繰り返し計算を行い, 各画素の水深を輝度値と して画像化した（図一6）。

この図より地すべり地域は水系の近傍に位置し, しか

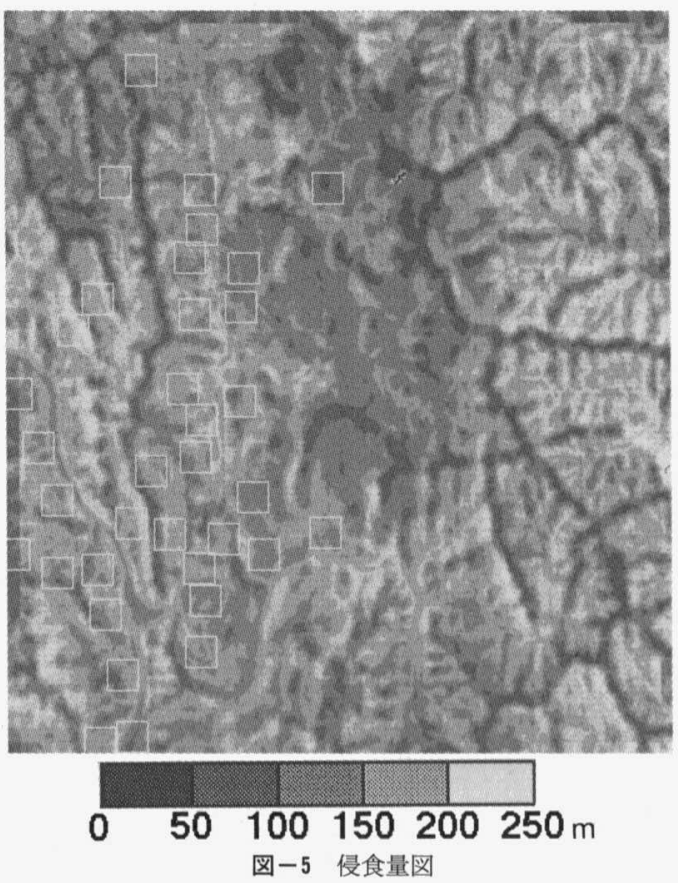


もストレーラの河道次数 3 以上の本流沿い或は合流点付 近に位置するものがほとんどであった。

以上のように DTM より考察した結果, 地すべり地域 の位置は水系沿いで, 地形的にみて新しい地形浸食圏で 発生していることが判った。岡林ら (1978) ${ }^{4) 5)}$ は高知県 中央部の地すべりについて, 四国山地の隆起と河川侵食 との面から考察し, 過去に形成された谷底低地や谷壁末 端部の緩斜面が，段丘面や山腹緩斜面となって残されて いる侵食前線と呼ばれる地域に地すべりが多いと指摘し ている。ほほ同一標高に地すべり地域が分布していたこ とは, 四国の地すべりが地殼上昇・地形侵食など地形形 成と密接な関係にあることを暗示している。しかし四国 では，第四紀の地質学が未発達なので言明は出来ない。 むしろ四国では, 地すべりの研究が第四紀の地質学を明 らかにするかも知れない。

\section{2 衛星データを用いた土地被覆分類}

土地被覆状態を人工衛星データを用いて分類する。今 回人工衛星データとして, LANDSAT TM データを用 いた(図-7)。この衛星は地上分解能 $30 \mathrm{~m}$ で，7 バンド の波長域を持つセンサを搭載しており，土地被覆状態を 見るには適している。そこで本節では, LANDSAT TM データより植生図・土地被覆分類図を作成し, 地すべり 地域の分布を考察する。

\subsection{1地すべりと植生}

本研究で用いた LANDSAT TM などのマルチスペク トル画像は，植生指標を算出することが出来る。つまり 植生の反射率の高い近赤外バンドの観測值と, 逆に植物 の反射率の低い可視の赤バンドの観測值とをバンド間演 算することによって, 植生の情報を強調することが出来

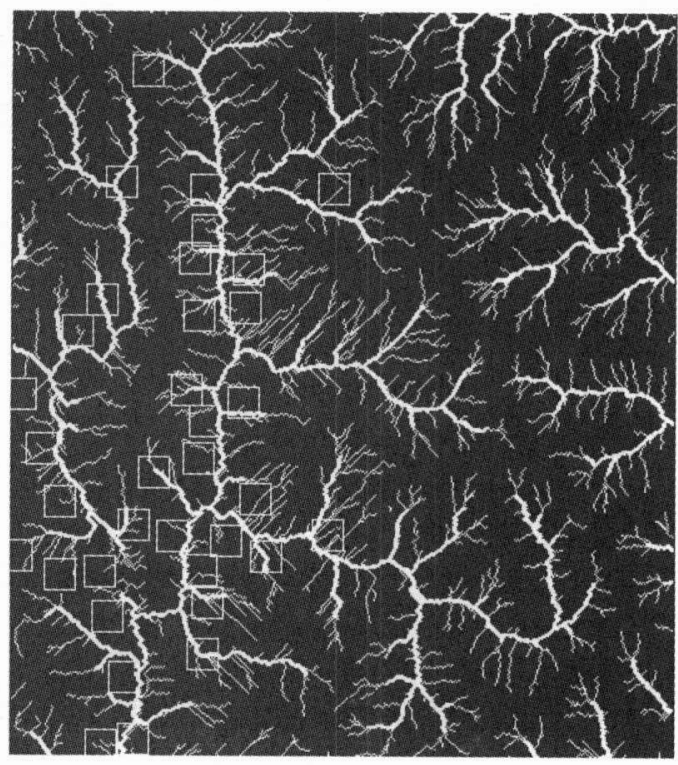

図一～水系図
る。特に正規化植生指標（NVI）として次式は広く使わ れている6。

$$
N V I=\frac{I R-R}{I R+R}
$$

$I R:$ 近赤外バンド

$R$ : 赤バンド

LANDSAT TM データにおいては，赤バンドはバン ド 3, 近赤外バンドはバンド 4 に対応している。したがっ てこの式を用いて NVI 画像を作成した(図－8)。この図 より地すべり地域は植生の比較的多いところに位置して いることが判る。植生の少ないところにも地す心゙り地域 が位置しているものもあるが，これらの地域は水田地帯 である。本研究で用いた LANDSAT TM データは 5 月 に取得されたものであり,この時期水田は湛水状態にあ るため低い NVI 值として現われた。NVIで水域と無植 生地域とを区別するのは困難であるため, 次項で別の分 類法を試み土地被覆状態について詳しく考察する。

\section{2 .2 地すべりと土地被覆状況}

衛星データを用いた土地被覆分類法には教師付分類と 教師なし分類とに大別できる。教師付分類の場合トレー ニングデータは現地調査結果などに基づいて人為的に作 りだされ, 教師なし分類の場合トレーニングデータは統 計量に基づいて自動的に作り出される。一般に現地調査 結果がある場合，教師付分類の方が正確に分類できる ${ }^{6)}$ 今回は対象地域において既に現地調査を行っているので, その結果に基づいてトレーニングデータを作成し最尤法 分類を 7 バンド全てを用いて行った。最尤法分類とは, 各階級に対する画素データの尤度を求め, 尤度最大の階 級にその画素を分類する方法である。今回，分類階級は

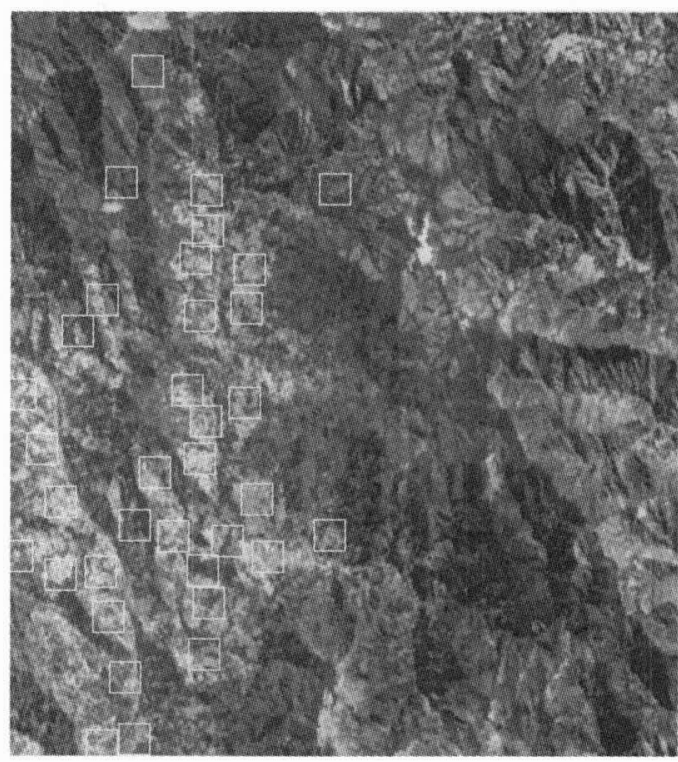

図-7 LANDSAT TM 画像 


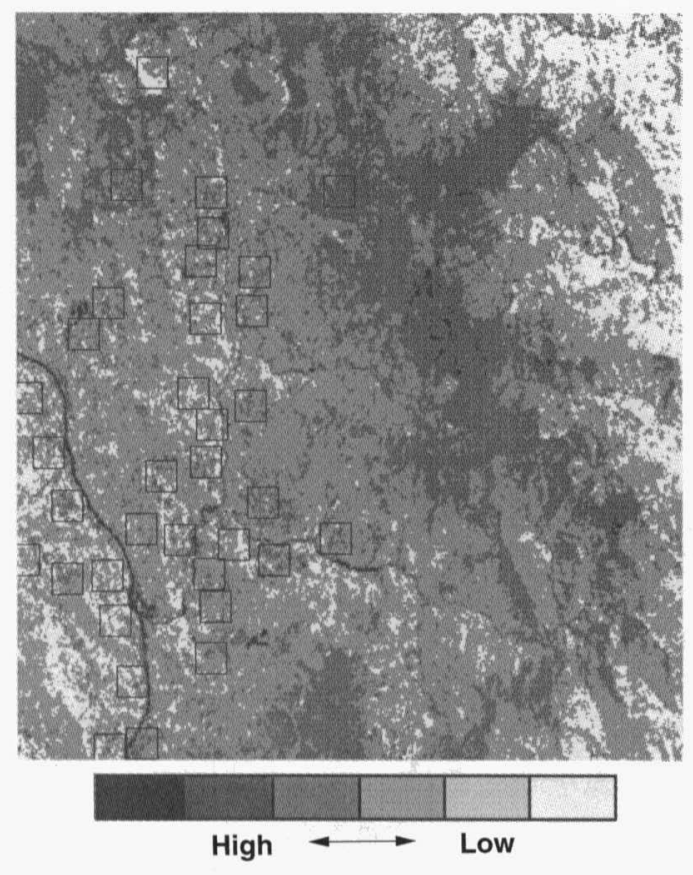

図-8 NVI 画像

水田・針葉樹・広葉樹・裸地の 4 階級とした。分類結果 を図 -9 に示す。この図より対象区域内全地すべり防止 区域のうち，32\%は水田地域・43\%は針葉樹林地域に分 布していた。対象地域における針葉樹林地域のほとんど は植林によるものであるから, 水田地帯とあわせれば地 すべり地域の $75 \%$ は農地・林地として積極的に利用され ていることになる。特に水田地域は水の豊富な地域であ るため地すべりと密接な関係にあると言える。

\section{DTM・衛星データを用いた地すべりの危険 度判定}

本節では地すべりの危険度判定を試みる。対象地域を 含む四国の破砕帯地すべりを対象に, 筆者らは既に現地 調査・室内実験を終えている ${ }^{10111)}$ 。調査・実験内容は地す べり規模の測定, 地すべり地域における土の土質実験な どである。これらデータと前節で作成した画像とを用い て危険度の判定を試みる。

\section{1 危険度判定手法}

斜面安定解析は現在までに様及な方法が考案されてい る。近年では有限斜面における安定計算法において, 円 弧すべり計算は Fellenius（1927), Bishop（1955）らの 方法が, 非円弧すべり計算はJanbu(1957), Morgenstern (1965), Spencer (1968) らの方法が一般に用いられてい る。そして安定計算法に浸透水を考慮するために; 計算 に用いられる強度常数に有効応力と間隙水圧の概念を取 り入れて計算する場合もある。つまり, 厳密に斜面の安

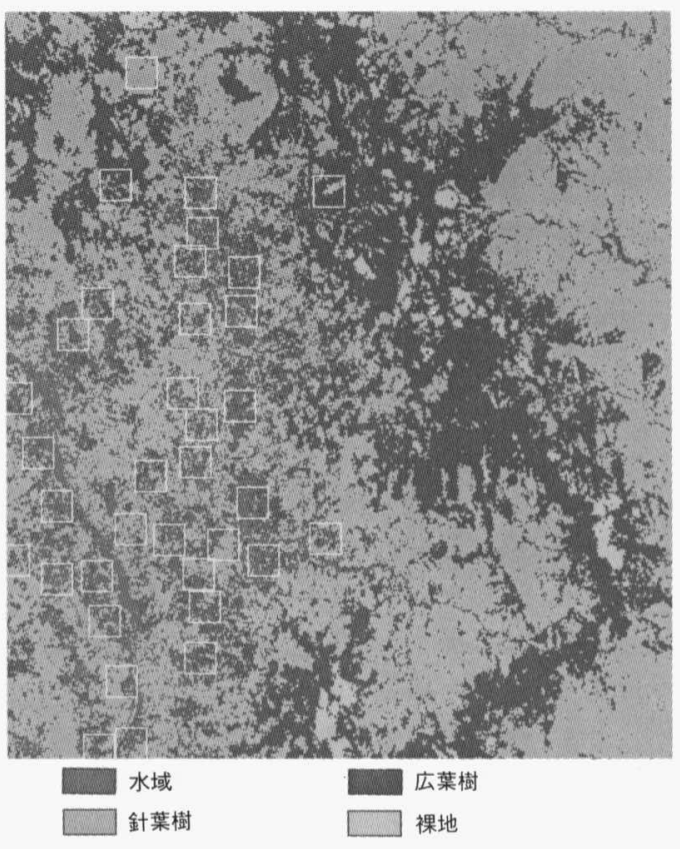

図-9 土地被覆分類図

定性を解析するには, すべり面の形状・土質条件などの 正確な情報を必要とする。本研究は対象区域内全域にお ける斜面の安定性の傾向を求めるのが目的であり, しか も斜面安定解析で用いるパラメータは衛星データゃ DTM から推定するため厳密なものとは言い難いうえ, 得られるパラメータの数も少ない。したがって, 円弧す ペりを対象とし, 最もパラメータの少ない簡便法（Fellenius 法)を用い, しかも土質条件は全応力表示で解析を 行った。

この方法において斜面の安定性は, 次式のように地す ベり土塊の抵抗モーメントと滑動モーメントの比（安全 率)で表される。

$$
\begin{aligned}
F_{s}= & \frac{\Sigma N}{\Sigma T} \quad \begin{array}{l}
T=R \cdot W \cdot \sin \alpha \\
N=R(C \cdot L+\tan \phi \cdot W \cdot \cos \alpha)
\end{array} \\
R & : \text { すべり円弧の半径 }(\mathrm{m}) \\
a & : \text { スライス底辺の角度 (Degree) } \\
L & : \text { スライス底辺の長さ }(\mathrm{m}) \\
A & : \text { スライスの面積 }\left(\mathrm{m}^{2}\right) \\
W & : \text { スライスの重量 }(\mathrm{tf} / \mathrm{m}) \\
& W=\gamma_{t} A \quad \gamma_{t} \text { 土の湿潤密度 }\left(\mathrm{tf} / \mathrm{m}^{3}\right) \\
\phi: & \text { 内部摩擦角 }(\text { Degree }) \\
C: & \text { 粘着力 }\left(\mathrm{tf} / \mathrm{m}^{2}\right)
\end{aligned}
$$

この式を DTM 上の各画素に適用し, 地すべり危険度 判定図を作成する。つまり DTM はグリッドデータであ るため，それぞれのグリッドを斜面安定解析における土 塊のスライスとして取り扱うことができる(図-10)。判 

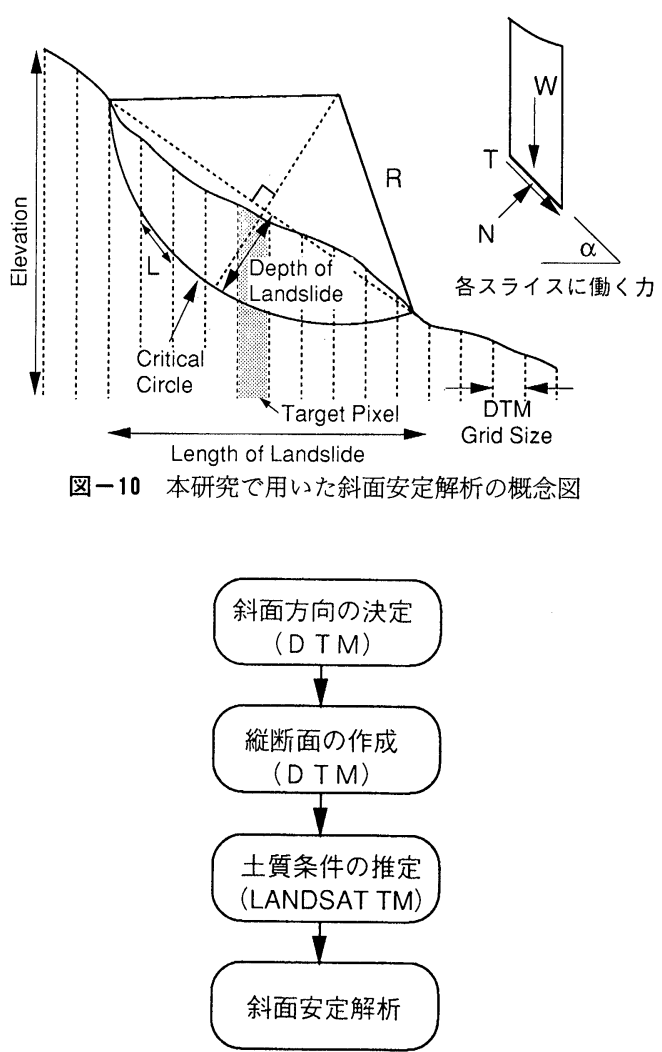

図-11地すべり危険度判定流れ図

定図作成の流れは次のとおり（図-11）。

a . 斜面方向を決定（最も急勾配の方向を斜面方向と する)

b. 想定地すべり断面をDTM より作成

c 。各スライスの土質条件を地質デー夕・衛星デー夕 より推定

d. 斜面安定解析により安全率を算出

e.マッピング

このとき予測する地すべりの規模 $(R)$ は現地調査に よって得られた結果を基に決定し，また土質条件（ $\gamma_{t}$, $C, \phi)$ は室内実験によって得られた結果を基に推定す る。

\section{1 .1 想定地すべりの規模}

本研究では, 水平長さ $240 \mathrm{~m}$, スベリ深さ $30 \mathrm{~m}$ の比較 的大きい規模の地すべりを対象として危険度の予測を行 う。図-12に四国における地すべりの水平長さとスベリ 深さのヒストグラムを示す10)。この図より四国の地すべ りは通常水平長さ $60 \sim 100 \mathrm{~m}$, スベリ深さも $10 \mathrm{~m}$ 程度 の小さいもので多いが， $240 \mathrm{~m}$ を越えるような大規模な 地すべりも発生しており，大きな被害を与えたという例 がいくつかある。地すべりの被害を考えたとき，大規模 地すべりを想定した危険度判定図の方が有効であろう。

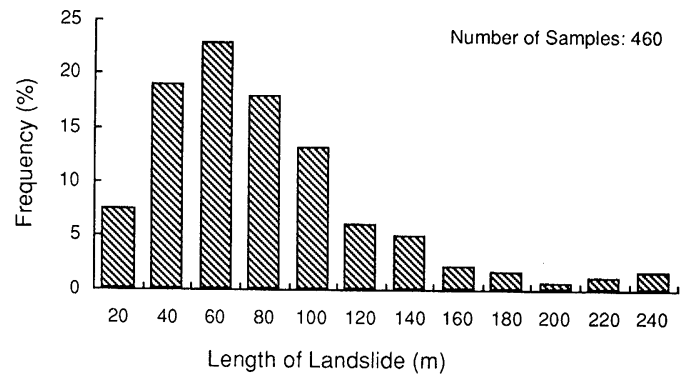

a) Histogram of Landslide Length



b) Histogram of Landslide Depth

図ー12 四国における地すべりの規模

また, LANDSAT TM 及び DTM の格子幅が $30 \mathrm{~m}$ と大 きいため，小規模の地すべりを想定するには無理がある。 本来想定されるべき地すべりの規模は実態に即すべきで あるが，それについては細かい DTM を作成した上で改 めて報告したい。したがって今回は前出の大規模地すべ りを想定し解析を進めた。なお，想定した規模における 地すべり円弧の半径 $(R)$ は，約 $700 \mathrm{~m}$ であった。

\section{1 .2 土質条件}

土の単位体積重量: 対象地域およびその周辺における 土の単位体積重量を室内実験により求めたところ, 単位 体積重量のほとんどが $1.8 \sim 2.0 \mathrm{tf} / \mathrm{m}^{3}$ であった。した がって, 本解析では $1.9 \mathrm{tf} / \mathrm{m}^{3}$ を代表值として計算する。

セン断強さ: 対象地域およびその周辺における土の内 部摩擦角と粘着力を一面セン断試験によって求めた (図-13)。その結果, 自然状態（不飽和状態）における 内部摩擦角は $7 \sim 40^{\circ}$, 粘着力は $2.0 \sim 8.0 \mathrm{tf} / \mathrm{m}^{2}$ の範囲に あった。ところで, セン断強さは地質帯によって異なる。 今回我々は地質帯ごとに土質を調査することはできな かったが，特に三波川帯の結晶片岩を母岩とした土は風 化の進行が速いため粘土化され易く, セン断強さは非常 に弱いと言われており ${ }^{12)}$ ，実際地すべり発生頻度も高い。 したがって, 表一 1 に示すように地質帯毎にセン断強さ を仮定した。

土地被覆状態の影響: セン断強さは土の水分状態に よって全く異なる。つまり飽和状態の土の粘着力は, 自 然状態のそれの約 $1 / 2$ にすぎない（図－13）。したがっ て，その効果を土地被覆状態から推定する。なお，土地 被覆状態は2.2.2 で求めたものを用いる（図一9)。教師 


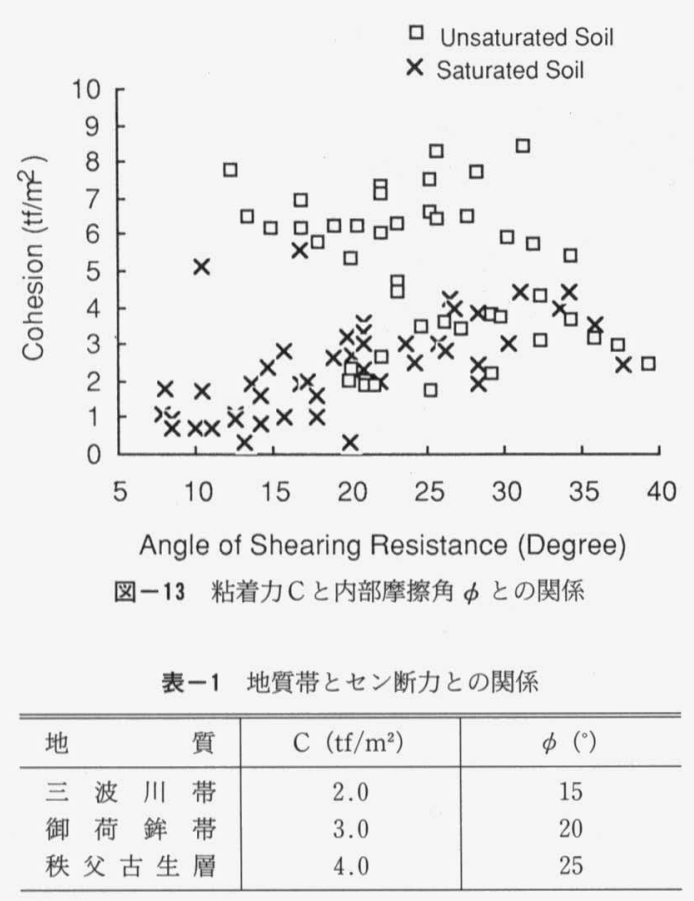

表一2 土地被覆状態とセン断力低下割合との関係

\begin{tabular}{|c|c|c|c|}
\hline \multicolumn{3}{|c|}{ 土地被覆状態 } & \multirow{2}{*}{$\frac{\text { 粘着力低下割合 }}{0.5}$} \\
\hline 水 & & 域 & \\
\hline 針 & 葉 & 樹 & 0.7 \\
\hline 広 & 葉 & 樹 & 1.0 \\
\hline 裸 & & 地 & 1.0 \\
\hline
\end{tabular}

付最尤法分類によって 4 階級, 水域 (水田を含む) ・針葉 樹林帯・広葉樹林帯・裸地に分類したが, これら階級の うち, 土壤水分が多いと予想される土地被覆状態は, 水 田地帯である。また，対象地域において針葉樹林帯は谷 筋に分布しているため, ある程度の土壤水分が予想され る。したがって, 表一2 に示すように土地被覆状態と粘着 力の低下割合を仮定した。

\section{2 危険度判定結果}

以上のように仮定した土質条件のもと，大規模地すべ りを想定した斜面安定解析を全対象地域内 DTM の各 画素毎に行う。つまり全画素について, それぞれの画素 を中心に $240 \mathrm{~m}$ の範囲ごとに斜面安定解析を行うこと になる(図-10 参照)。これによって得られる安全率を各 画素の地すべり危険度とし, 危険度判定図を作成した。 そして,この危険度判定図上に行政機関が指定した地す ベり防止区域を矩形でプロットした。図ー14に危険度判 定結果を示す。この図より $90 \%$ の地すべり防止区域は, 安全率がほぼ1.0, あるいはそれ以下と判定された地域 に位置していた。一方, 安全率ほほ 1.0 以上と見られる 地域にも地すべり防止区域となっている地域は，御荷鉾

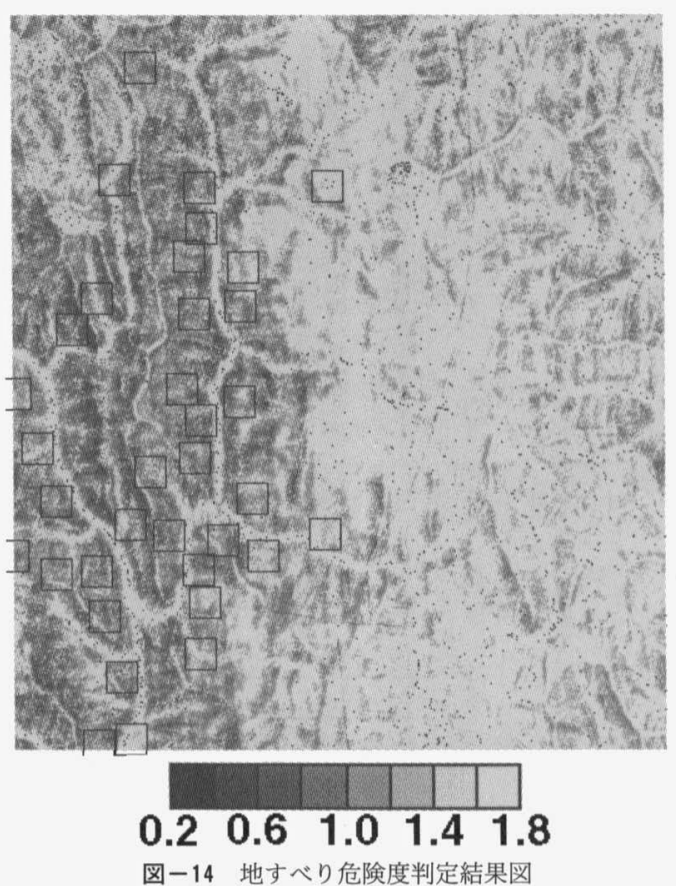

帯に位置していた 2 地区であった。これは御荷鍄帯にお ける地形はなだらかであることが影響していると見られ る。つまり, 三波川帯と御荷鉾帯とでは地中内部の構造 の相違から地すべりの発生機構が異なるためと考えられ る。

今回, 斜面安定解析における土質条件は大まかに仮定 したが, 危険度判定図として非常に精度の高いものと言 えるであろう。四国のように地質帯ごとに土質の特徵が 異なる場合, 本研究で試みた危険度評価法は有効な手段 と考えられる。

\section{4.おわりに}

地すべり地域の分布状態について, DTM 及び LANDSAT TM 画像から考察を行った。その結果 DTM より 地すべり地域は地形と地質・地形侵食・水系と密接な関 係にあることが，LANDSAT TM 画像より地すべり地 域は水系に近いことから水が豊富で，地すべり活動に よって土層も深い。したがって, 四国は平野が少ないた め, 地すべり地域であろうと農林地として積極的に利用 されているのであろう。

今回さらに斜面の釣合状態だけに着目して DTM・衛 星デー夕より危険度判定図を作成し良好な結果を得た。 しかし，DTM の格子幅の点や土質パラメータ決定法の 点でまだ十分な危険度判定図とは言い難い。今後, DTM の精度向上, 航空写真の利用, 的確な土質試験法とその 利用法を考えなければならない。またこの危険度判定図 からは，いつ地すべりが発生するかを予測することは出 
来ない。それは地すべりは地中内部ですべり面が形成さ れて発生する現象であるため, 地中内部の状態（特に地 下水状態）を完全に把握しない限り, その発生予測は困 難をきわめるであろう。1992 年に運用が開始された JERS 1 衛星のデータは合成開ロレーダにより土壌水分 の予測が可能と見られている。さらに今後マイクロ波放 射計を搭載した衛星も打ち上げられる。これらのデータ を地すべり解析に反映させる手法も確立せねばならない。

\section{参考文献}

1) 根本正美・村井俊治: Landsat TM および DTM を用い た活断層地形の特徵抽出, 日本写真測量学会, 平成 3 年 度年次学術講演会発表論文集, pp. 33-36, 1991

2 ) 姜健華・村井俊治ほか: DEM からの接嶺面図の作成につ いての研究, 日本写真測量学会, 平成 4 年度年次学術講 演会発表論文集, pp. 145-148, 1992

3) 村井俊二・越智士郎: リモートセンシングと地理情報シ ステムの結合に関する研究(1), 生産研究 41 巻 8 号, pp. $37-40,1989$

4 ) 岡林直英・栃木省二 - 鈴木 士・中村三郎-井上公夫: 高 知県中央部の地形, 地質条件と土砂の災害との関係(1), 地すべり, Vol. 15, No.2 (54) pp. 3-10, 1978
5 ) 岡林直英・栃木省二・鈴木 士・中村三郎・井上公夫: 高 知県中央部の地形, 地質条件と土砂の災害との関係(2), 地すべり, Vol.15, No.3 (55) pp. 30-37, 1978

6 ) 高木幹雄・下田陽久 監修: 画像解析ハンドブック, 1991, 東京大学出版会, pp. $643-688$

7 ）吉松弘行・清水清文・坂元靖秀: 地すべり斜面の地形解析 による地すべり判読と危険度判定, 地すべり, Vol. 15, No. 4 (56) pp. $12-19,1979$

8 ) 古谷尊彦: 破砕帯地すべりの予察的研究, 地すべり, Vol. 4, No.2 (11) pp. 21-31, 1967

9 ) 藤田 崇・平野昌繁・波田重起: 徳島県川井近傍の地すべ りの地質構造規制, 地すべり, Vol. 13, No.1 (45) pp. $25-36,1976$

10）高木方隆・中村忠春・宮内定基：四国における地すべりの 分布, 地すべり学会誌, Vol. 26, No. 3, pp. 21-26, 1989

11）高木方隆・中村忠春・宮内定基: 愛媛県における地すべり 地域の地表勾配, 地すべり学会誌, Vol. 26, No. 4, pp. $29-36,1989$

12）高橋治郎・谷田部龍一・稲田善紀・横田公忠: 面河川（仁 淀川）沿いの地すべり地の地形と地質的特徵, シンポジ ウム地すべり地形に関する諸問題論文集, pp. 107-113, 1992

13) Masataka TAKAGI, Shunji MURAI and Takasi AKIYAMA: "Generation of Land Disaster Risk Map from LANDSAT TM and DTM Data", International Archives of Photogrammetry and Remote Sensing, Vol. XXIX Part B 7, pp. 754-758, 1992

（原稿受理日 平成 5 年 1 月 20 日）

\section{平成 6 年度 (財)砂防・地すべり技術センター 研究開発助成募集の御案内}

\section{財団法人 砂防・地すべり技術センター 理事長 矢野勝太郎}

当財団では毎年度研究開発助成事業を実施しています。 助成は砂防ならびに地すべりおよびがけ崩れ対策に関す る技術の向上を図るため,これらに関する技術開発およ び調査研究を対象として, 特に問題意識が鮮明で達成目 標が具体的であるテーマで, 優れた人材を結集し十分な 遂行能力を有する大学, 高等専門学校等の研究者に対し て実施しております。

平成 6 年度も研究開発助成を実施するため募集を行う ものです（募集受付け期間は平成 6 年 4 月 1 日〜 30 日)。
募集内容は「平成 6 年度 砂防・地すべり技術センター 研究開発助成募集要領」に示されておりますので, 必要 な方は下記へ請求して下さい。

（請求先）

財団法人 砂防・地すべり技術センター 企画研究部 (担当: 加藤)

干 162 東京都新宿区砂土原町 3-4（生泉市ヶ谷ビル） TEL 03-3267-8014, FAX 03-3267-8040 (FAX 申込 可) 
有限要素法による地すへり斜面の漫透流解析と光れに基づいた斜面安定解析

「地すべり」Vol. 30, No. 4 (通巻第 116 号) pp. 1～11，1994 年（平成 6 年） 3 月

稲葉 一茂, 吉田 昭治, 竹内 伸一, 中野 俊郎, 佐藤 修

有限要素法による新簡易解析法によって, 浸水性の異なる土層区分とすべり面を難透水層と仮定した 2 次元水 理モデルを，地下水圧の 2 次元的な観測データと同程度の精度でもって同定した。このモデルによって，すべり 面に沿った 2 次元的な間吵水圧分布を求めて安定解析を行った結果, 例えば，東虫亀地すべり地では，すべり面

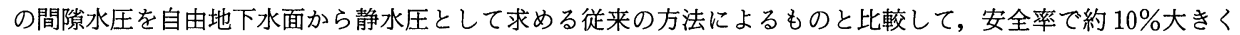
なった。

\section{再滑動型地すべりの移動機構}

「地すべり」Vol. 30, No. 4（通巻第 116 号）pp. 12１9, 1994 年（平成 6 年）3月 丸山 清輝, 吉田 克美

本報告では，再滑動型地すべりの移動機構についてリングせん断試験を行い，すべり面粘土のせん断特性，再 滑動型地すべりの移動機構を検討した。その結果, 滑動力が残留強さより小さい場合, 変位を生じることなく残 留強さまで滑動力に抵抗できることが分かった。また, リングせん断試験結果を用いて $\phi_{r}{ }^{\prime}$ と $W_{L}, W_{P}, I_{p}$, 粘 土含有量との関係を多変量解析により検討した結果， $W_{L}$ と $W_{P}$ から $\phi_{r}{ }^{\prime}$ が推定できることが分かった。

マスムーブメントの性質と物質構成・水・応力場

「地すべり」Vol. 30, No. 4 (通巻第 116 号) pp. 20 27, 1994 年（平成 6 年） 3 月 中山 康

マスムーブメントは, 物質構成とどのような応力場に置かれているかで性質が規定される。とくに土の場合に は粒度組成が大きな意味を持ってくる。近年発表された数多くの研究成果を基にして，これを検討した。

\section{DTM 及び衛星データを用いた地すべり危険地域の抽出}

「地すべり」Vol. 30, No. 4（通巻第 116 号）pp. 28～35, 1994 年（平成 6 年） 3 月

\section{高木 方隆, 村井 俊治}

数值地形モデル（DTM）及び人工衛星デー夕（LANDSATTM）を用いて四国の中央部 $13 \times 14 \mathrm{~km}$ を対象に 地すべり解析を試みた。DTM からシェーディング画像・切峰面図・水系図を作成し, 人工衛星データから植生図・ 土地被覆分類図を作成し, 地すべり地の分布状態を考察した。その結果地すべり地は地表水や地中水の集中する 地域に分布しており，地形浸食と密接な関係にあることが判った。

さらに，これらのデータと現地調査および室内実験結果を用いて対象地域内全域の地すべり危険度マップを斜 面安定解析により作成した。その結果，90\%の地すべり防止区域は危険とみられる地域に位置し，良好な結果を 得ることが出来た。

\section{ニューラルネットワークの地すぺり対策杭の設計手法選定への応用}

「地すべり」Vol. 30, No. 4 (通巻第 116 号) pp. 36 40, 1994 年（平成 6 年） 3 月 吉松 弘行, 藤田 無雄

地すべり対策杭は，従来は地すべり地のすべり面形態などの特性要因によりその設計手法が選択されていたが, これまでの既設杭工データをニューラルネットワークを用いて学習させることによって，杭工のたわみ量が予測 でき，ニューラルネットワークが地すべり対策杭設計手法の支援システムになることを示した。

\section{日南海岸（国道 220 号線）の斜面崩壊}

「地すべり」Vol. 30, No. 4（通巻第 116 号）pp. 41～45, 1994 年（平成 6 年） 3 月

高谷 精二

国道 220 号線の宮崎市堀切峠と日南市風田 $29.9 \mathrm{~km}$ 間は, 日向灘に面する急な斜面を切りとった道路のため, しばしば崩壊する。ここで発生する崩壊は次の四つに分類することができた。(1)層厚 5 〜 $15 \mathrm{~m}$ の砂岩のブロック 状崩壊, (2)モルタル剥離崩壊, (3)泥岩上にある砂岩の岩盤すべり, (4)表層土の崩壊。

\section{感圧式すべり面検知器}

「地すへり」Vol. 30, No. 4 (通巻第 116 号) pp. 46～51，1994 年（平成 6 年） 3 月

丸山 清輝, 山崎 宣悦

既存の計測器によるすべり面判定法の問題点を解消するために, 感圧式すべり面検知器の開発を行った。そし て，その精度を確認するために室内及び現地において試験を実施した。その結果，室内試験では，設計通りの性 能を得ることができた。また，現地試験では，累積移動量約 $20 \mathrm{~mm}$ ですべり面深度を求めることができた。 